\title{
Forenzní aspekty technologie a umístění VIN motorových vozidel
}

\section{Forensic Aspects of VIN Technology and Location in Vehicles}

\author{
Petra Kolitschová, Roman Rak \\ Vysoká škola finanční a správní, Karlovy Vary
}

\begin{abstract}
Abstrakt
Vehicle Identification Number (VIN) je jednoznačný, celosvětově unikátní identifikátor vozidla. Př́spěvek popisuje zásady jeho umístění na vozidle, způsob jeho vyhotovení (výroby) a v neposlední řadě i ochrany před negativními faktory tak, aby zůstala zachována jeho identifikační hodnota a zároveň aby proces identifikační kontroly vozidla byl jednoznačný, rychlý a efektivní. V textu jsou rozebrány různé pohledy na VIN ze zorného úhlu výrobců vozidel, administrativně-správních orgánů (využívajících identifikaci vozidla v celonárodních registrech vozidel) a orgánů činných $\mathrm{v}$ trestním řízení při vyšetřování a dokazování automobilové kriminality.
\end{abstract}

Klícová slova: umístění, výroba, ochrana, Vehicle Identification Number, originalita vozidla

\section{1. ÚVOD}

Základním identifikátorem vozidla v automobilové, policejní, forenzní i administrativně správní praxi (registrace vozidel a její využití pro účely státní správy) je VIN (Vehicle Identification Number), který je definován v mezinárodních normách. VIN je celosvětově unikátní, neopakovatelný identifikátor, jedinečný pro každé vyrobené vozidlo [1], [5].

Aby bylo možné odcizené nebo jinak závadové vozidlo znovu zaevidovat, aniž by bylo odhaleno při kontrolách v policejním informačním systému i národním či mezinárodním ${ }^{1)}$ registru vozidel, pachatel musí skrýt (zaměnit) původní identifikátor VIN odcizeného vozidla. Tuto skutečnost znají profesionální zloději i výrobci motorových vozidel. Výrobci různými technologiemi, umístěním VIN na různých a různě přístupných částech vozidel maximálně stěžují proces nelegální změny, výměny VIN. Aby jejich snahy byly účinné, musí ale zároveň existovat efektivní

\footnotetext{
1) V měřítku EU pomocí technologie EUCARIS (European Car and Driving
} Licence Information System).

\begin{abstract}
Vehicle Identification Number (VIN) is a worldwide unique vehicle identifier. The paper describes the principles of its location on the vehicle, the way it is produced and, last but not least, the protection against the negative factors so that its identification value is preserved and that the vehicle identification process is clear, fast and efficient. Various views of the VIN from the perspective of vehicle manufacturers, administrative authorities (using vehicle identification in national vehicle registers) and law enforcement bodies in investigating and proving automotive crime are discussed in the text.
\end{abstract}

Key words: location, production, protection, Vehicle Identification Number, vehicle originality

kontroly originálnosti VIN ze strany státních a profesionálních institucí, ke kterým patří znalost umístění VIN a způsob realizace VIN pro různé modely vozidel, včetně jeho zabezpečení různými ochrannými prvky [1], [2].

\section{HISTORIE A SOUČASNOST}

Identifikátor VIN (Vehicle Identification Number) se v praxi reálně, povinně, celosvětově používá od roku 1986. Pojem VIN je v praxi ale znám již z dvacátých let minulého století, kdy jej používali někteří němečtí výrobci vozidel [2].

VIN má být podle př́slušných norem na vozidle realizován:

- V takové části vozidla, která je primárně neoddělitelná od základního celku vozidla. V prŕípadě samonosných karosérií to je tedy samotný skelet karosérie a VIN by neměl být např. vyznačen $v$ dílu, jako je blatník či jiná vyměnitelná součást (která se mění $\mathrm{v}$ případě poškození vozidla). V případě rámových konstrukcí vozidel (obvykle u terénních vozidel - Toyota Hilux, VW Amarok 


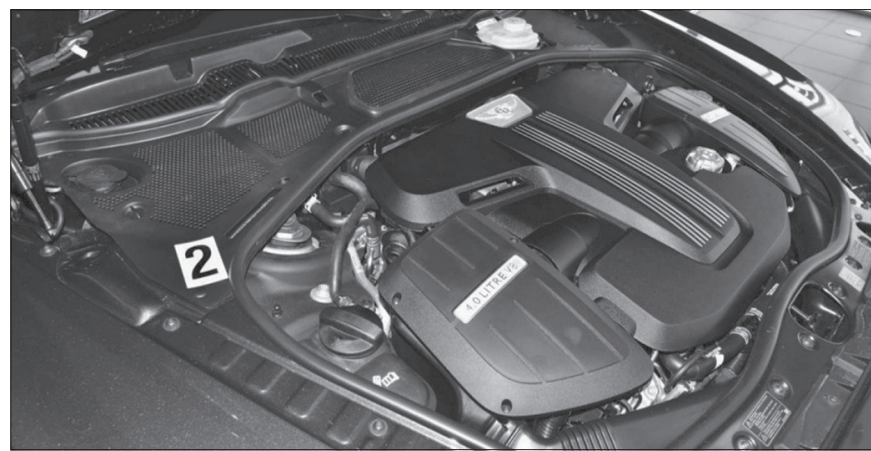

Obr. 1 Standardní umistěni VIN v motorovém prostoru vozidla Bentley Continental GT. VIN je lehce vizuálně př́stupný (vpravo od čislice ,2" ").

Fig. 1 A standard VIN position in the engine compartment of a Bentley Continental GT vehicle. The VIN is easily visually accessible (to the right from the number ,,2“).

apod., nákladních vozidel obecně) je VINem označován rám karosérie (obvykle vzadu u zadního kola). Ze základní myšlenky „neoddělitelnosti identifikátoru VIN od základního celku vozidla vyplývá prímo i technologie jeho vyhotovení. Identifikátor VIN nemůže být nijak nanýtován, nalepen, nastříkán apod. na kov (nebyl by neoddělitelný), ale je vyhotoven technologií, která bezprostředně, objemově, plasticky zasahuje do integrity kovu - tedy je vyražen, vybroušen, gravírován přímo do materiálu kovu, čímž po sobě zanechává neopakovatelné identifikační stopy i z hlediska způsobu jeho vytvoření. Jinými slovy - technologie vyhotovení VIN do kovu vozidla má destruktivní charakter.

- Tak, aby byl dobře dostupný (př́stupný, viditelný). $\mathrm{Z}$ hlediska dostupnosti identifikátoru VIN rozlišujeme přímou, vizuální dostupnost pouhým zrakem nebo dostupnost po jednoduchém odstranění určitých zákryvných částí, dílů vozidla atd., které lze snadno odklonit, otevřít, odehnout, posunout, otočit apod., takže

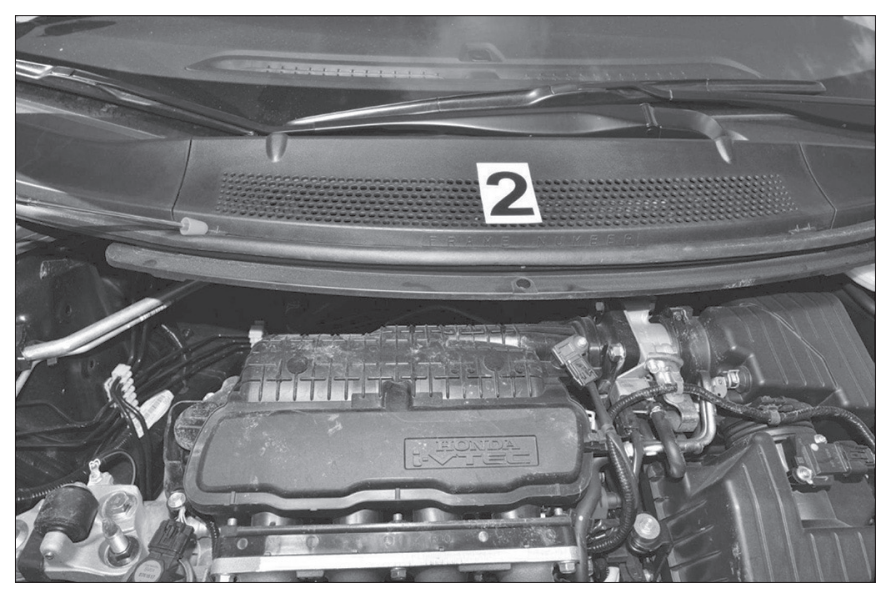

Obr. 2 Ukázka těžko prístupného VIN u vozidla Honda Civic. Aby byl identifikátor vizuálně prìistupný, musí dojit k odborné demontáži plastových diliu.

Fig. 2 Example of a difficult-to-access VIN in a Honda Civic vehicle. For the identifier to be visually accessible, plastic parts must be expertly dismantled.
VIN je i pak jednoduše vizuálně pozorovatelný, aniž bychom pro zpř́istupnění potřebovali nějaké specializované znalosti či dovednosti. Jednoduchý zákryv VIN mívá důvody $\mathrm{v}$ estetice (VIN není napřs. prrímo vidět v interiéru, podlaze vozidla mezi nohami spolujezdce), nebo v ochraně identifikátoru (před znečištěním, poničením, př́istupem vody, korozí apod.). Jiní výrobci realizují umístění VIN na vozidle tak, že je nutné nejprve odstranit některé díly, součásti vozidla a k tomuto je nutné použít bud' specializovaných nástrojů, nebo speciálně školených osob (např. sejmutí stěračů čelních skel speciálními klíči, aby tak bylo možné odmontovat plastový kryt, pod kterým je identifikátor fyzicky umístěn). Hovoříme pak o dostupnosti identifikátoru pomocí profesionálního zásahu. Tento postup v určitém smyslu ale popírá myšlenku dobré př́stupnosti VIN, nezbytné pro orientační identifikaci vozidla, pokud nevíme, kde ukrytý VIN pod díly či součástkami vozidla vůbec hledat.

- Tak, aby byl dobře čitelný. Z tohoto důvodu dle př́islušných norem musí být font písma VIN minimálně $6 \mathrm{~mm}$ vysoký, abychom jej dokázali přečíst lidským zrakem bez použití optických přístrojů. Poměrně problematickou otázkou je dobrá čitelnost identifikátoru v čase. Nejde totiž jen o to, aby identifikátor byl čitelný bezprostředně po výrobě vozidla, ale v celém jeho životním cyklu, tedy až po fyzickou likvidaci vozidla, jeho sešrotování, včetně identifikačních znaků - abychom si byli jisti, že bylo sešrotováno právě toto a ne jiné vozidlo. Jinak hrozí zneužití ,ppozůstalých“ identifikátorů pro vytvoření nové, pozměněné (padělané) identity jiného vozidla. Čitelnost VIN, zaznamenaného do kovu se časem mění z mnoha důvodů - poškozením VIN, znečištěním VIN (olej, prach, mycí prostředky a jiné provozní kapaliny) a především korozí. Výrobce, který si je vědom této hrozby, má vícero možností, jak identifikátor ochránit.

- Tak, aby byl bezpečně čitelný. Tato zásada patří bezpečnosti osob, které s identifikátorem pracují, tedy provádějí jeho kontrolu, a to zejména př́mo v silničním provozu. Z tohoto důvodu rozumní výrobci umist'ují VIN u vozidel určených pro evropský trh (tedy jezdící po pravé straně vozovky) na pravou stranu vozidla. Policista, kontrolující identifikátory v běžném provozu, pak stojí blíže okraji vozovky a nemůže být ohrožován provozem ostatních

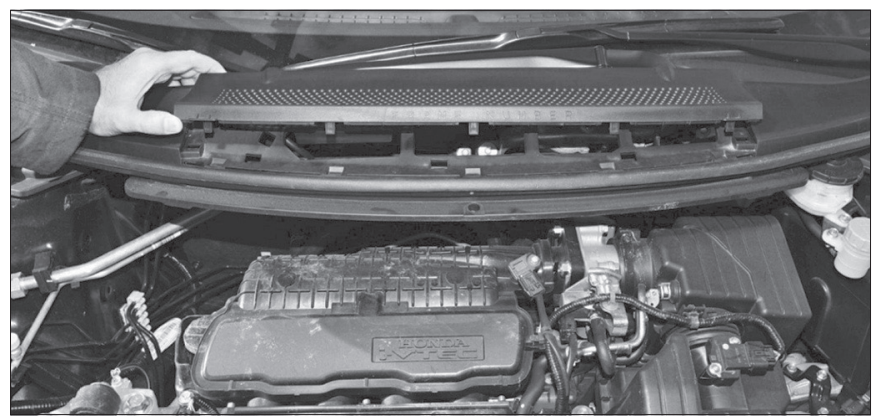

Obr. 3 Ukázka demontáže plastového krytu v prostoru před stěrači čelního skla.

Fig. 3 Demonstration of a dismantled plastic cover in the space in front of the windscreen wipers. 


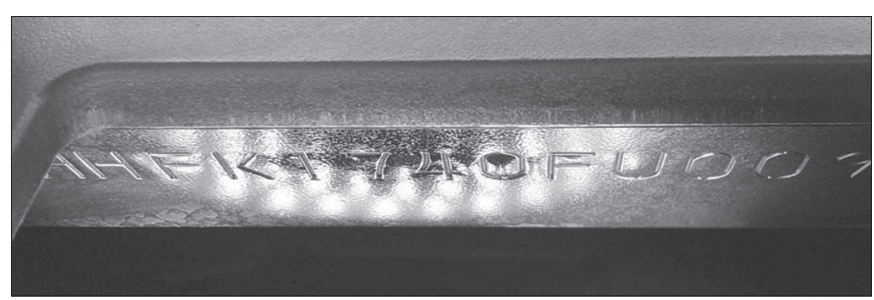

Obr. 4 I po demontáži je identifikátor celkově vizuálně nepř́stupný. Odečitáni VIN je velmi nekomfortni, svou roli hraje i šikmá plocha.

Fig. 4 Overall, the identifier is visually inaccessible even following this dismantlement. Reading the VIN is very uncomfortable, and the inclined surface plays a role as well.

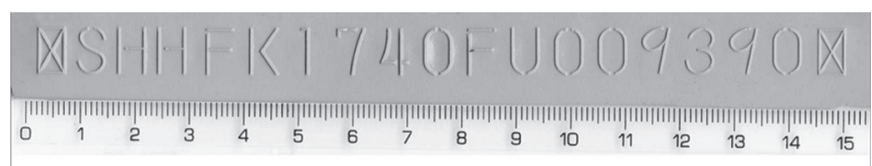

Obr. 5 V kriminalistické praxi se v takovýchto připadech pro účely dokumentace použivaji plastické otisky pomocí speciálni hmoty (v tomto prípadě ISOMARK), které jsou velmi citlivé a umožňuji následnè podrobně pozorovat otisk $v$ jeho detailní podobè.

Fig. 5 In forensic practice, plastic prints by means of a special compound (ISOMARK in this case) are used in such cases for documentation purposes. They are very sensitive and make it possible to observe the print in detail in its detailed form afterwards.

vozidel, zejména pak za zhoršených světelných podmínek. Toto pravidlo je účelné aplikovat jak pro identifikátory VIN ražené do kovu karosérie, tak i na tzv. homologační nálepky, nesoucí rovněž identifikátor VIN (dnes již zpravidla tištěné na samolepící nálepku).

- Tak, aby byl nezaměnitelný. Místně i ve větším rozsahu okolí. VIN musí být vytvořen tak, aby byla v maximální míře ztížena jeho př́ípadná nelegální změna, jejíž cílem je změnit obsah identifikátoru a tím celkovou identitu vozidla. VIN je proto ražen různými technologiemi a různými fonty písma. Na začátku a konci VIN se používají speciální oddělovací znaky (tzv. delimitery), které určují rozteč (délku) VIN pro každý model vozidla. Tato délka je konstantní.

\section{OCHRANA VIN PŘED POŠKOZENÍM, ZNEČIŠTĚNÍM A KOROZÍ}

Základní ochranou Vehicle Identification Number (VIN), kterou musí výrobce zajistit, je ochrana pro zachování podmínky dobré čitelnosti. Od provozních kapalin, prachu, poničení a po působení koroze se VIN stává v některých svých částech nebo celkově nečitelný a tedy v praxi nepoužitelný. Na ochranu VIN před výše uvedenými faktory mají vliv:

- umístění;

- ochranné mechanické zákryty;

- ochranné laky a pokryvy.

V praxi se pak můžeme setkat s kombinací výše uvedených faktorů.

\subsection{Umístění identifikátoru VIN}

Identifikátor VIN lze umístit v interiéru vozu nebo v jeho exteriéru [3]. Pod pojmem interiér obecně chápeme vnitřní část prostoru vozidla, určeného pro cestující. VIN je umistován zpravidla v podlaze pod sedadlem spolujezdce, na vnitřní, spodní straně „rámu“ karosérie, za zadní opěrkou mezi zadními sedadly apod. $\mathrm{V}$ interiéru vozidla jsou identifikátory nejlépe chráněny před všemi vnějšími vlivy a proto je toto místo v posledních letech pro umístění identifikátorů velmi časté (např. u vozidel Hyundai) i z důvodu, že VIN je většinou lehce prístupný (není nutné např̀.

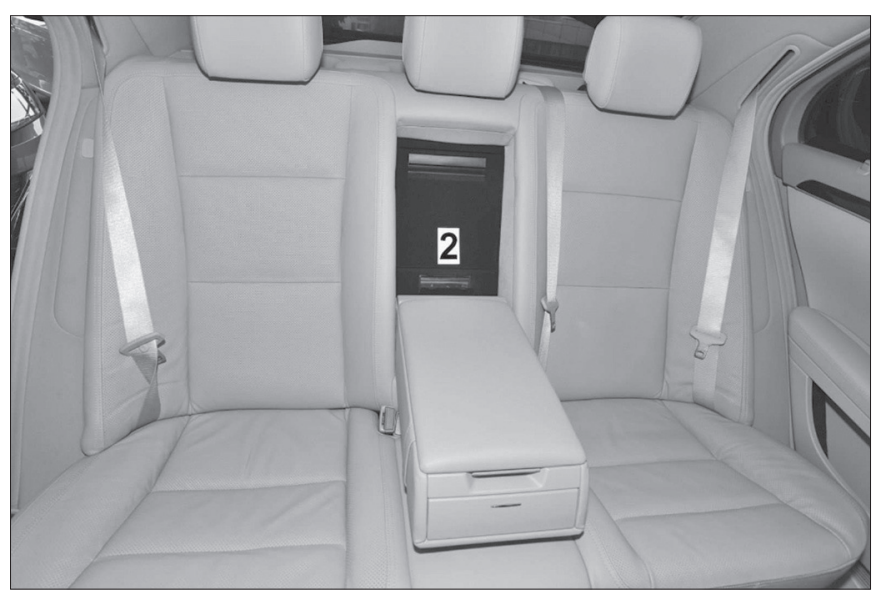

Obr. 6 Nestandardně umístěný VIN u vozidla Mercedes - Benz tř́dy , S“ v prostoru za loketní opěrkou zadních sedadel. Málokoho napadne zde identifikátor hledat. Na druhé straně tento prostor je čistý, bezprašný, takže identifikátor není vystaven žádnému negativnímu puisobení okolních jevi.

Fig. 6 A VIN located in a non-standard way in a Mercedes - Benz „S " class vehicle in the space behind the elbow rest of the rear seats. It occurs to hardly anyone to look for the identifier there. On the other hand, this space is clean, dust-free so the identifier is not exposed to the negative effects of ambient phenomena.

vyndávat věci ze zavazadlového prostoru, kde je obvykle ukryt až pod odnímatelným dnem).

Mezi interiérem a exteriérem můžeme definovat přechodovou zónu, kterou je motorový a zavazadlový prostor vozidla. Zavazadlový prostor je u osobních automobilů (pokud se nejedná o vozy typu pick-up) rovněž chráněn před vnějšími, zejména povětrnostními vlivy. VIN může být $\mathrm{v}$ této oblasti pouze zanesen nečistotami z přepravovaného materiálu. Př́ístupnost VIN je ale omezená u vozidla naloženého zavazadly. Pro př́stup k identifikátoru VIN pak musí být náklad nejprve vyložen, což není zcela komfortní při operativním prověřování bezpečnostními složkami, zejména při zhoršených povětrnostních podmínkách „,na ulici“.

Identifikátor VIN nacházející se $\mathbf{v}$ motorovém prostoru bývá obvykle, až na určité výjimky, dobře umístěn, takže je viditelný na první pohled po otevření víka motorového prostoru. Zde byl VIN v minulosti hojně umist'ován, zejména po horních bocích karosérie; v přední, horní části dělící přepážky mezi kabinou a motorovým prostorem. VIN se pak umist'uje spíše vlevo (pokud stojíme čelem $\mathrm{k}$ otevřenému motorovému prostoru vozidla $\mathrm{v}$ jeho přední části, proti čelnímu sklu) nebo symetricky podle pomyslné zado-přední podélné osy vozidla. $\mathrm{V}$ jiných př́padech VIN nalezneme v levé 

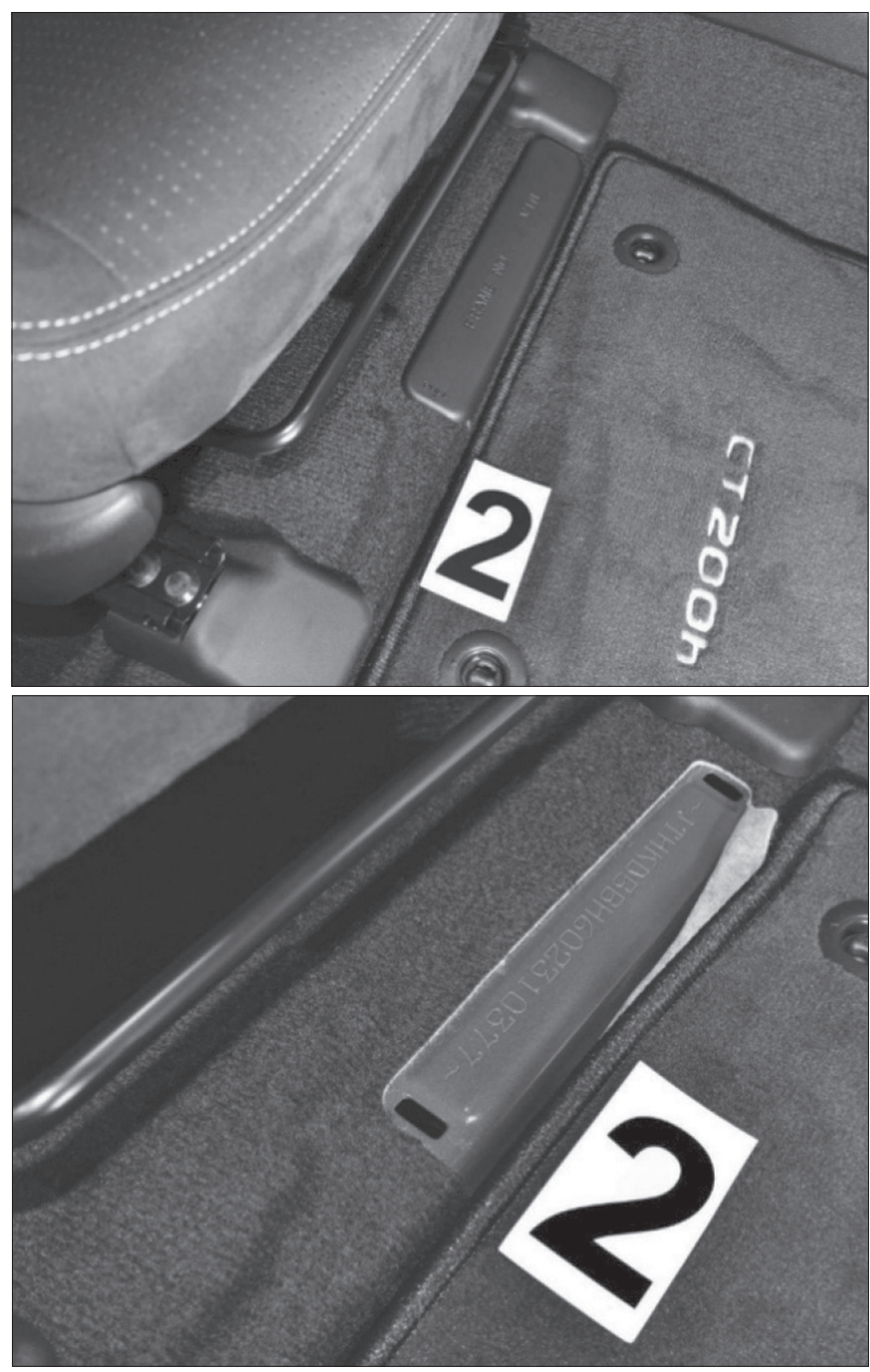

Obr. 7 Standardně umistěný VIN vozidla Lexus CT 200h pod sedadlem spolujezdce. VIN je chráněn plastovou krytkou před poškozením a pošpiněním.

Fig. 7 The VIN of a Lexus CT 200h vehicle standardly placed below the front passenger's seat. The VIN is protected by a plastic guard against damage and soiling.

a pravé horní části karosérie, ke které se přichycují blatníky vozidla. Vozidla tovární značky BMW mívají VIN umístěný na tlumičích.

VIN u starších vozidel $\mathrm{v}$ motorovém prostoru může být více znečištěn než v interiéru nebo zavazadlovém prostoru vozidla: je zde větší vlhkost, prašnost, možnost koroze, nebot' motor ze své spodní části není nikdy zcela zakrytován, obvykle vůbec. $Z$ důvodu ochrany před tímto druhem fyzického a chemického působení je přes VIN nalepována ochranná transparentní fólie, mající dvojí roli: protekce před uvedenými vnějšími fyzikálně-chemickými vlivy a před svévolnými zásahy osoby, mající nelegální důvod VIN pozměnit. O rozsahu potenciálního fyzikálně-chemického poškození způsobeného zejména provozem vozidla a vnějším okolím vozidla (např. klimatické podmínky) rozhoduje i volba horizontálního či vertikálního umístění identifikátoru VIN, stejně tak i dalších, podobných identifikátorů: z vertikálních ploch lépe stéká voda, provozní kapaliny, méně se usazuje prach, takže míra znečištění i koroze bývá v praxi podstatně nižší, než u identifikátorů, jež jsou umístěny na horizontálních plochách. U horizontálních

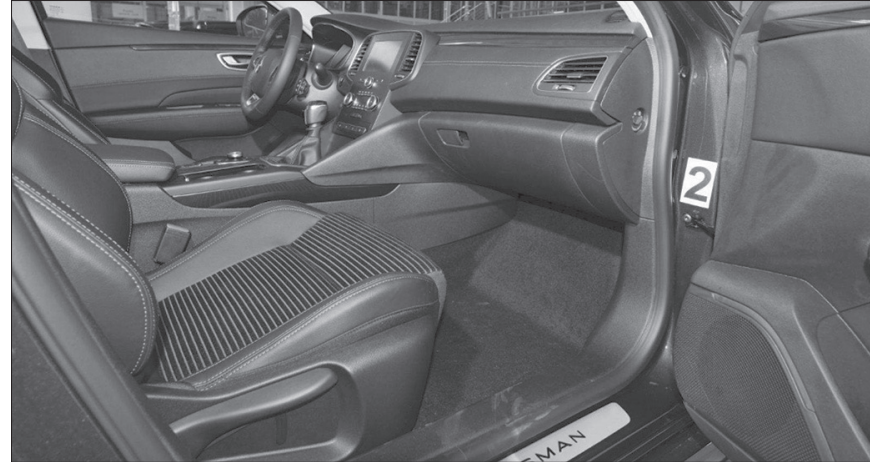

Obr. 8 Renault Talisman. VIN je umistěn neobvykle svisle v prostoru tzv. „A-sloupku“. Při svislém umistění na VIN tolik neulpivaji nečistoty, voda a provozni kapaliny.

Fig. 8 Renault Talisman. The VIN is positioned unusually vertically in the space of the A-pillar. When the VIN is positioned vertically, dirt, water and service fluids do not cling to it as much.

ploch je pak na místě právě použití různých ochranných přelepů transparentními fóliemi, pořizování různých ochranných laků, voskových vrstev apod. Z důvodu lepší ochrany VIN před korozí někteří výrobci umist’ují identifikátor svisle do předního (tzv. A) sloupku vozidla (některé modely Renault, Dacia).

U vozidel s rámovou konstrukcí se VIN umist'uje zpravidla externě, na spodní rám vozidla. Obvykle jej najdeme na rámu u zadního kola, často překrytý ochranným lakem, voskem, asfaltovou hmotou. Externě se VIN umist'uje i u některých dodávek, do oblasti předního kola. Tato umístění nejsou ale moc zdařilá, protože je VIN v těchto místech zpravidla přikryt blátem a pokud nevíme, kde jej přesně hledat, velmi těžko ho nalezneme. Navíc takováto umístění jsou prístupná obvykle až po vytočení kol volantem do jednoho z krajních směrů (vlevo, vpravo). Externí identifikátory bývají zpravidla umist'ovány z pravé strany vozidla, aby bylo zaručeno bezpečí při př́stupu k identifikátoru a zkoumající osoba se nenacházela na straně hustého provozu na pozemní komunikaci. Umistování směrem k „chodníku“ ale může být problematické u těch modelů, které jsou výrobci dodávány současně na trhy s pravostranným a levostranným silničním provozem.

\subsection{Ochranné mechanické zákryty}

Používání ochranných mechanických zákrytů má několik důvodů, které mohou být v logickém souběhu. První důvod je mechanický. Ochranný kryt zabraňuje pádu nebo př́stupu nečistot či drobných předmětů do otvoru, přes který je zajištěn přímý vizuální přistup k VIN, technologicky zhotoveném v kovovém materiálu. Druhý důvod bývá estetický, tj. vizuální zakrytí otvoru s identifikátorem VIN a jeho „estetické“‘ zakomponování zejména do interiéru vozidla tak, aby vše „ladilo“.

Mechanické zákryty identifikátoru VIN jsou běžné, pokud je VIN vyhotoven v podlaze vozidla (obvykle pod sedadlem spolujezdce), nebo ve vnitřní interiérové části vozidla v oblasti tzv. „A“ sloupku (sloupek karosérie mezi čelním sklem a předními dveřmi vozidla), v podlaze vozidla u nohou spolujezdce pod palubní deskou nebo na vnitřní straně rámu dveří nad podběhem. U některých vozidel je VIN výjimečně umístěn za sklopnou loketní opěrkou mezi zadními sedadly apod.

V interiéru vozidla bývá mechanický zákryt realizován bud' pouze jako součást spodního koberce položeného na kovovou 
podlahu vozidla, který bývá ve výrobě lehce naříznut; nebo pomocí plastové, odklápěcí nebo zcela oddělitelné krytky. V prvním případě je někdy nezbytné pro zajištění prvního přístupu $\mathrm{k}$ VIN opatrně ostrým nožem doříznout koberec tak, abychom nepoškodili lak podlahy pod ním a zároveň zbytečně nerozšiřovali naříznutí koberce. Pokud je VIN umístěn pod nohami spolujezdce (nikoliv tedy pod jeho sedadlem), je nutné nejprve odejmout krycí, odnímatelný koberec z tkaniny nebo gumy.

Plastové krytky (převážně černé nebo šedé barvy) bývají dobře viditelným způsobem označovány vylisovaným nápisem „VIN“, ,frame number" apod. Plastové krytky jsou konstruovány tak, že se pomocí působení nevelké síly odklopí nebo je musíme opatrně „podebrat“" nástrojem, podobným šroubováku. Některé odklápěcí krytky jsou nasunuty na př́stupový otvor k VIN, takže je možné je opatrně vysunout i s jejich obvodovým plastovým rámečkem. U některých specifických vozidel (aktuálně vyráběná luxusní vozidla Mercedes Benz třídy S) je plastová krytka součástí př́stupu k pojistkové skř́ňce vozidla, u které je zároveň na karosérii vyražen VIN). V takovýchto prrípadech označení VIN na plastové krytce absentuje.

V motorovém prostoru je identifikátor VIN chráněn mechanickým zákrytem obvykle v dělicím prostoru mezi motorovou částí a kabinou vozidla. V tomto př́ípadě bývá VIN umistován nedaleko spodní hrany čelního skla vozidla (např. některé vozy Peugeot, Citroen, Honda). Zákryv bývá bud' plastický (obdobný výše popsanému řešení), nebo dokonce jen z odhlučňovacího materiálu, pokrývajícího kapotu motoru. Odhlučňovací materiál může být pro zpevnění uchycen nastřelovacími kovovými sponkami $\mathrm{k}$ podkladovému materiálu, připomínající karton papíru. Zákryv VIN je uchycen pomocí otočného čepu, takže se vytáčí směrem vzhůru nebo dokonce jen na ,suchých zipech“.

Ve výjimečných prŕípadech je VIN schován pod plastovým krytem, táhnoucím se podél celého čelního skla. K zajištění př́stupu $\mathrm{k}$ VIN je pak nutné opatrně rukou demontovat těsnící gumu a opatrně v rohu nadzdvihnout plastový kryt.

Ve zcela výjimečných př́ípadech je pro zajištění přístupu k VIN nutné realizovat odbornou demontáž některých komponent, ke které jsou nutné specializované nástroje. Př́íkladem může být vozidlo Renault Kadjar, kde je potřeba nejprve demontovat stěrač na čelním skle za pomoci speciálního klíče, abychom uvolnili k nadzdvihnutí plastový kryt.

\subsection{Ochranné laky a pokryvy}

Ochranné laky a pokryvy mají v praxi dvojí účel: primárně chrání před poškozením, znečištěním a korozí identifikátor VIN realizovaný do kovu karosérie a zároveň, sekundárně zajišt'ují ochranu před neodbornými zásahy, které mohou mít za cíl změnit identitu vozidla pomocí změny VIN. V tomto případě ochranné laky a pokryvy napomáhají garantovat originálnost provedení VIN pomocí originálnosti, původnosti ochranných laků a pokryvů.

Identifikátor VIN je tím více náchylný ke korozi, čím je na vozidle umístěn níže na jeho exteriérové části směrem k vozovce. Největši korozi je vystaven tedy $\mathrm{v}$ těch př́padech, $\mathrm{kdy}$ je ražen do rámu vozidla $\mathrm{v}$ jeho podvozkové části a zároveň není nijak zvlášt' dále chráněn. Někteří výrobci vozidel vyhotoví identifikátor VIN, aniž by jej alespoň přestříkali základní barvou.

Tento prrístup ale naštěstí patří spíše jen minulosti. V současné době je identifikátor na exteriéru vozidla zpravidla chráněn

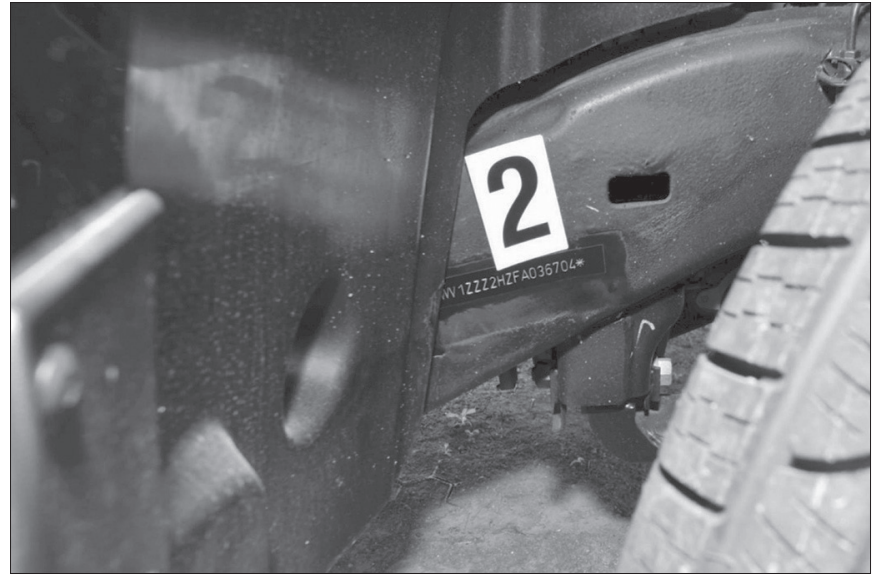

Obr. 9 Volkswagen Amarok. Identifikátor VIN je umistěn vně vozidla na jeho podvozkové části a chráněn transparentním prelepem.

Umístěni VIN v této části vozidla je pro praktickou kontrolu nepríliš štastné - nepohodlné (musíme se shýbat a zároveň vytáčet kola), podvozek vozidla bývá velmi často silně znečištěn, takže musime přesně vědět, kde identifikátor hledat. Identifikátor je po několika letech provozu silnè zkorodovaný, takže jeho čitelnost prudce klesá.

Fig. 9 Volkswagen Amarok. The VIN identifier is located outside the vehicle on its chassis part and is protected by a transparent cover label. Placing the VIN in this part of the vehicle is not too fortunate - comfortable for practical inspection (one has to bend down and, at the same time, turn the wheels), the vehicle chassis tends to be very heavily fouled, so one has to know exactly where to look for the identifier. After several years of operation, the identifier is severely corroded, so its legibility decreases abruptly.

gumoasfaltovými nebo voskovými či pryskyřicovými ochrannými nástřiky, nátěry nebo jinak nanesenými ochrannými vrstvami.

V motorovém prostoru němečtí výrobci (Audi, Bentley, BMW, VW, Škoda, Seat apod.) překrývají VIN samolepícími transparentními nálepkami, které primárně chrání identifikátor před poškozením, znečištěním a korozí a zároveň sekundárně upozorňují, že identifikátor VIN je nutné chránit i před všemi pokusy o jeho nelegální alternaci. Na vozidlech Land Rover / Range Rover má samolepící transparentní nálepka barevné, varovné okraje, které výrazným způsobem dávají najevo, že se jedná o nedotknutelnou ochrannou zónu.

Ochranné samolepící, transparentní nálepky jsou zhotovovány z materiálů, které musí odolat agresivnímu prostředí (mycí a čistící prostředky, provozní kapaliny apod.) v motorovém prostoru; neměly by vlivem času, teploty, vlhkosti a UV záření křehnout, matnit a samovolně se odlupovat. Zároveň by neměly být beze stop lehce odstranitelné, př́ípadně znovu nalepitelné.

O intenzitě vlivu koroze na identifikátor (výrobní číslo) rozhoduje i jeho konstrukční umístění na vozidle. Pokud je identifikátor umístěn na horizontální plochu, je větší pravděpodobnost, že zde bude zůstávat vlhkost, nečistoty a agresivní látky a tak koroze bude intenzivněji prostupovat materiálem.

Umístění identifikátorů, ražených znaků na svislé plochy je z tohoto pohledu mnohem lepší, protože zde nezůstává tolik iniciátorů negativních reakcí. Tento přístup se používal zejména u francouzských a japonských vozidel, kdy se VIN umist'oval na svislou dělící plochu mezi motorovým prostorem a kabinou pro přepravu osádky. 
O korozijních procesech rozhoduje i volba materiálu, do kterého je VIN ražen. Pokud je materiálem eloxovaný hliník v různých podobách, nebo kompozitní materiály (zejména u luxusních vozidel), koroze neprobíhá, nebo respektive jen velmi, velmi pomalu.

\section{ZÁVĚR}

Znalost fyzického umístění VIN, způsobů jeho zhotovení a všech faktorů, majících vliv na zachování VIN v jeho původní, originální podobě, má rozhodující vliv na efektivní práci při identifikaci vozidla. V kovu karosérie vozidla vyražený VIN (Vehicle Identification Number) je klíčovým, primárním identifikátorem každého vozidla $\mathrm{v}$ celosvětovém měřítku a tedy i předmětem nelegálního zájmu pachatelů, kteří se snaží skrýt skutečnou identitu odcizeného nebo jinak závadového vozidla.

Aby kontroly vozidla byly účinné, je nutné současně, na jednom místě (tj. v jedné lokalitě) kontrolovat fyzickou shodu identifikátor VIN na vozidle, $\mathrm{v}$ jeho dokladech a $\mathrm{v}$ př́slušných informačních systémech. V opačném př́padě je velmi pravděpodobné, že skutečná identita vozidla může být skryta.

Znalost fyzického umístění VIN u každého vozidla je základní podmínkou pro každou identifikační kontrolu vozidla. Každé vozidlo (v závislosti na modelu, roku výroby) má identifikátor umístěn na jiném místě a proto znalost tohoto umístění dokáže podstatně časově zkrátit proces identifikační kontroly.

Zákonitosti působení různých negativních faktorů (jako je koroze, provozní poškození, zašpinění, snahy pachatelů o změnu identifikátoru apod.) umožňují lepší pochopení problematiky fyzické identifikace vozidla, tedy i lepší, kvalitnější, bezpečnější zhotovení identifikátoru VIN na každém vozidle.

\section{LITERATURA}

[1] MATOUŠKOVÁ, I., MORAVČÍK, L., RAK, R. et al. eCall, intelligent transport system (legal, technical, informational and psychological aspects). Magnet Press Slovakia, Bratislava, 2015, s. 189-215. ISBN 978-80-89169-31-3, EAN 9788089169313.

[2] MORAVČÍK, L'. Vehicle Crime and some Problems by its Solutions in Slovakia. Security theory and practice, Police academy, 2016, 2, s. 89-100. ISSN 1801-8211.

[3] MORAVČÍK, L. Automotive crime in Slovakia and problems in its solution. In: Proceedings of the $13^{\text {th }}$ International Symposium held on September 8, 2016 at the International Fair Security Bratislava 2016, Academy of the Slovak Police Forces in Bratislava, 2016, Bratislava, s. 128-140. ISBN 978-80-8054-691-5, EAN 9788080546915.

[4] MORAVČÍKOVÁ, J. Cross-Border Exchange of Information about Traffic Offences through EUCARIS. In: Automotive safety 2016: proceedings of the X International Science-Technical Conference: 22-24 February 2016, Kielce University of Technology, Kielce, 2016, s. 227-234. ISBN 978-83-63792-70-1.

[5] MORAVČÍKOVÁ, J. eCall - Legislation and preparedness of the Slovak Republic. In: Crisis Management - Security of Regions: Proceedings of the $9^{\text {th }}$ International Scientific Conference: 21-22 June 2016. Karel Englisch College, Brno, 2016, s. 238-247. ISBN 978-80-86710-87-7.

[6] TUREČEK, J. et al. Police technique. Aleš Čeněk, Praha, 2008, 316 s. ISBN 978-80-7380-119-9.

[7] TUREČEK, J. Rentgens. In: Security Magazin, 1997, 4, s. 17-19. ISSN 1210-8723.

\section{Správná citace:}

KOLITSCHOVÁ, P., RAK, R. Forenzní aspekty technologie a umístění VIN motorových vozidel. Soudní inženýrství, 2018, 29(4), 9-14. DOI: http://dx.doi.org./10.13164/SI.2018.4.9. ISSN 1211-443X. 